\title{
Description of Anxiety Levels of Midwifery Students : Literature Review
}

\section{Luluk Mukarromah ${ }^{1}$, Ivon Diah Wittiarika ${ }^{1}$, Samsriyaningsih Handayani ${ }^{1}$}

${ }^{1}$ Airlangga University, Mayjen Prof Dr Moestopo number 47, Surabaya 60132. Indonesia

email : luluk.mukarromah-2018@fk.unair.ac.id

\begin{abstract}
Background: Midwifery study programs around the world operate with the aim of training and producing competent midwives. Special attention and a good learning process are essential in ensuring that learning objectives can be achieved. Midwifery is considered as one of the educational programs that require high academic scores, therefore it consumes a lot of time and effort. Such high demands and pressures can trigger depression and anxiety. This study aims to describe the level of anxiety of midwifery students which is useful as an effort to assess student welfare in learning determined by a Midwifery Education Institution in dealing with what is experienced by students. Literature review through searching scientific publications in the period 2016-2021 using several databases, namely Pubmed, ScienceDirect and Google Scholar. 8 articles are gathered and discussed in the literature review, after meeting the inclusion and exclusion criteria. Literature results are $\mathrm{N}=113$, Pubmed N=53, Direct Science N=49, Google Scholar N=11. Can unlock that the students are on average at very pleasant scores which can be overcome with the support of providing psychoeducation and stress management by midwifery students. A student counseling center with adequate facilities and qualified staff should be established on campus as students seek appropriate help for mental health problems.
\end{abstract}

Keywords:Anxiety Level; Midwifery Students

\section{Introduction}

The quality of midwives can be seen in terms of competence and education obtained when they were students. It plays a major role in influencing This is highly influenced by the academic environment and the abilities of each individual. The latest data collected by the Indonesian Health Workers Council (MTKI) in November 2015 mentions that they were as many as 353,003 registered midwives which showed the highest number compared to the number of other health workers (Interview with IBI Central Management, 2016).

The facts prove that there are various health problems related to the midwifery profession. One of these problems is that midwifery services have not been felt by all Indonesians due to many midwifery professions that have not developed from the aspect of competence and education, difficult access to midwifery services, there is a culture of childbirth by paraji/shaman, and government policies that do not encourage morale. placement of midwives in remote areas (Interview with IBI Central Management, 2016).

Anxiety is experienced by almost everyone in the world, including midwifery students who are relatively more stressed in terms of academics which are widely reported by universities, especially related to the mental health of midwifery students (Duffy et al., 2019).

Anxiety can affect student learning outcomes drastically as it tends to produce confusion and perceptual distortion. The perceptual distortion experienced by the individual can interfere with learning by reducing the ability to focus attention, shrinking memory, and reduces the capability to find correlations between things (Kaplan and Saddock, 2005). 
Student anxiety is described by a situation that makes a person feel afraid or uncomfortable, not confident, decreased learning concentration which affects learning achievement. It also includes physical disturbances in the form of shaking, tightness in the abdomen or chest, sweating profusely, sweaty palms, unstable emotions, dizziness, wanting to faint, to cause nausea that leads to other severity (Rasmun, 2009).

Yang, et al (2014) also confirmed that the factors that cause anxiety include the attitude of the exam supervisor, the atmosphere at the time of the exam, the skills possessed by students, the exam itself, and the internal feelings experienced by the students themselves, such as the feeling that they will not pass after facing the challenge. exam. To reduce anxiety, humans actually have self defense mechanisms, namely coping mechanisms and strategies. Coping mechanism helps humans to regulate and react upon their anxiety. Coping mechanisms can be interpreted in the way that individuals do in solving problems, adapting to changes and responding to threatening situations (Yang et al., 2014)

Students are expected to be able to adapts to all situations. This is important in order to avoid the occurrence of anxiety which has a higher risk in resulting other complications such as decreased concentration in learning, disturbed attention, decreased achievement index, restlessness or loss of control of a problem solving. Anxiety that is increasingly becoming a problem can be overcome by managing and controlling oneself and by providing psychoeducation to ease the burden on students' minds and reduce student anxiety. It is hoped that student' quality can be increased and plays a role in successing one of the SDGs program, improving maternal and child health.

It is important to emphasis on midwifery education in order to ensure the top-quality education that will increasing individuals' abilities to become midwives who are trained to carry out professional midwifery care. This skills laboratory test is shown as a medium for student evaluation based on knowledge in learning which is a source or trigger for student anxiety.

In Indonesia, Evianti (2010) showed that $48.4 \%$ of students experienced mild anxiety, $43.5 \%$ experienced moderate anxiety and $8.1 \%$ of students experienced severe anxiety. Siti N (2017) also mentions that the anxiety experienced by students is $26.4 \%$ of students who do not experience anxiety, $27.6 \%$ of students have mild anxiety, $32.2 \%$ of students are anxious on a moderate scale, then $13.0 \%$ are categorized as severe anxiety. and $0.8 \%$ experiences very severe anxiety.

Anxiety in facing exams is one of the mixed emotional manifestations experienced by a student as a reaction in an exam that can affect physical and psychological conditions. Apart from external factors, it is believed that there are genetic factors that contribute to a person's mental condition. Some individuals appear to be more resistant to stress and anxiety, while others appear to be more susceptible to stress and anxiety. Early depression and anxiety are associated with lifetime experiences such as drug and alcohol abuse, risky sexual behavior, suicide threats, poor academic results, and physical health problems (Werner-Seidler et al., 2017).

The skill laboratory test must be carried out quickly and accurately by the examinee. Examinees must also take a complete series of exams without missing a single element in a short test time ( \pm 10 minutes per skill), to get a good score. The skills laboratory focuses attention on the complete behavior of students, including coordinating intellectual skills, attitudes and interactions with others through clinical learning that has been obtained and practiced and is expected to be able to adapt as well as possible to avoid the occurrence of anxiety that will result such as decreased concentration in learning, disruption of learning. attention, decreased achievement index.

This literature review discusses the results of research that describe the level of anxiety of midwifery students in facing the skills laboratory exam.

\section{Method}

This literature review was carried out by searching for literature from scientific publications in the 20162021 range using several databases, namely Pubmed, Wiley Online, Science Direct, and Google Scholar. In the literature search in this study, using the keyword Anxiety "OR" Midwife Students "OR" Laboratory Skills Examination found 113 articles filtered according to title, abstract, 2016-2021. 
A search on Pubmed found 53 articles, then on Science Direct 49 articles were identified, and on Google Scholar 11 articles were found that matched. However, in the final process of filtering literature, all articles that have been found are readjusted to the inclusion criteria based on the title of the literature and after reading carefully, the results obtained are only 8 articles that match the objects discussed in the literature review. Inclusion and exclusion criterias are as below:

1. Inclusion Criteria

a. Research article on the level of anxiety of midwifery students in facing the skill laboratory exam

b. Publications between 2017-2021

c. Articles in Indonesian and English

d. Full text, journal articles, open access

2. Exclusion Criteria

a. Articles other than Indonesian and English

b. Literature review articles, systematic reviews, RCT 


\begin{tabular}{|c|c|c|c|c|c|c|}
\hline Number & Author & Research Title & Country & Method & Instrument & \\
\hline 1 & Choon Khim Teh & $\begin{array}{l}\text { Depression, Anxiety and } \\
\text { Stress among } \\
\text { Undergraduate Students }\end{array}$ & $\begin{array}{l}\text { Melaka Manipal } \\
\text { Medical College, } \\
\text { Malaysia }\end{array}$ & Cross Sectional Study & $\begin{array}{l}\text { DASS-21 } \\
\text { Questionnaire }\end{array}$ & $\begin{array}{l}\text { The prevalence of } \\
30.7 \%, 55.5 \% \text {, and } \\
\text { needs to be greater } \\
\text { students to improve }\end{array}$ \\
\hline 2 & Rini Lestari & $\begin{array}{l}\text { Student Anxiety Facing the Objective } \\
\text { Structured Clinical Assessment } \\
\text { (OSCA) Method Test at the } \\
\text { Muhammadiyah Midwifery Academy } \\
\text { in } \\
\text { Wringin Timur City }\end{array}$ & $\begin{array}{l}\text { Midwifery } \\
\text { Academy of } \\
\text { Muhammadiyah } \\
\text { Wringin Timur } \\
\text { City, } \\
\text { Indonesia }\end{array}$ & Cross Sectional Study & $\begin{array}{l}\text { TMAS } \\
\text { Questionnaire }\end{array}$ & $\begin{array}{l}\text { A total of } 38 \text { midy } \\
\text { have their anxiety } 1 \\
\text { at the level of seve } \\
\text { moderate anxiety ( }\end{array}$ \\
\hline 3 & $\begin{array}{l}\text { Mahbobeh } \\
\text { Faramarzi }\end{array}$ & $\begin{array}{l}\text { Test anxiety in objective structured } \\
\text { clinical examinations (OSCEs) } \\
\text { compared with traditional assessment } \\
\text { methods in undergraduate midwifery } \\
\text { students }\end{array}$ & $\begin{array}{l}\text { Babol University of } \\
\text { Medical Sciences, } \\
\text { Babol, Iran }\end{array}$ & $\begin{array}{l}\text { Descriptive analytical } \\
\text { study }\end{array}$ & $\begin{array}{l}\text { Test anxiety } \\
\text { inventory (TAI) }\end{array}$ & $\begin{array}{l}\text { All female midwife } \\
\text { Majority of the p: } \\
\text { students experienc } \\
\text { severe anxiety. }\end{array}$ \\
\hline 4 & $\begin{array}{l}\text { M. Saiful Bahri } \\
\text { Yusof }\end{array}$ & $\begin{array}{l}\text { Mental health of medical students } \\
\text { before and during medical education: A } \\
\text { prospective study }\end{array}$ & $\begin{array}{l}\text { Taibah University, } \\
\text { Malaysia }\end{array}$ & Cohort Study & $\begin{array}{l}\text { DASS-21 } \\
\text { Questionnaire }\end{array}$ & $\begin{array}{l}\text { The study showed } \\
\text { year medical stude } \\
\text { Factors that may } \\
\text { background, culutu }\end{array}$ \\
\hline 5 & $\begin{array}{l}\text { Edwin Timotius } \\
\text { Martua }\end{array}$ & $\begin{array}{l}\text { Comparison of Anxiety } \\
\text { Level on Medical Skill } \\
\text { Examination Between } \\
\text { Student of Medical } \\
\text { Faculty of Hnag Tuah } \\
\text { University, Surabaya }\end{array}$ & $\begin{array}{l}\text { Hang Tuah } \\
\text { University, } \\
\text { Surabaya, Indonesia }\end{array}$ & $\begin{array}{l}\text { Observational analytic } \\
\text { study }\end{array}$ & $\begin{array}{l}\text { Hamilton Rate } \\
\text { Scale for Anxiety } \\
\text { (HRSA) } \\
\text { questionnaire. }\end{array}$ & $\begin{array}{l}\text { This study measur } \\
\text { results were } 30 \\
\text { respondents with } n \\
\text { with moderate leve } \\
\text { student responden } \\
\text { respondents with } \\
\text { moderate levels of } \\
\text { severe levels of an }\end{array}$ \\
\hline 6 & $\begin{array}{l}\text { Kuganesh } \\
\text { Ravichandran }\end{array}$ & $\begin{array}{l}\text { The characteristic of anxiety disorder } \\
\text { among medical students of Universitas } \\
\text { Udayana, } \\
\text { Bali, Indonesia in the } \\
2019 \text { period }\end{array}$ & $\begin{array}{l}\text { Universitas } \\
\text { Udayana, Bali, } \\
\text { Indonesia }\end{array}$ & $\begin{array}{l}\text { A cross-sectional } \\
\text { study }\end{array}$ & $\begin{array}{l}\text { Depression } \\
\text { Anxiety and Stress } \\
\text { Scale- } 21 \\
\text { (DASS21) }\end{array}$ & $\begin{array}{l}\text { Of the } 75 \text { medical } \\
\text { experienced anxiet. } \\
\text { in very severe anxi } \\
\text { anxiety }(15.1 \%) \text {, ar }\end{array}$ \\
\hline 7 & Maulida Hariyani & $\begin{array}{l}\text { Anxiety of Sari Mulia } \\
\text { Level II Midwifery } \\
\text { Students When Facing the } \\
\text { Skill Lab Exam at AKBID } \\
\text { Sari Mulia Banjarmasin } \\
\end{array}$ & $\begin{array}{l}\text { AKBID Sari Mulia } \\
\text { Banjarmasin, } \\
\text { Indonesia }\end{array}$ & Analytical descriptive & $\begin{array}{l}\text { DASS-21 } \\
\text { Questionnaire }\end{array}$ & $\begin{array}{l}\text { The results showed } \\
\text { facing the Skill Lal } \\
52 \text { female students } \\
\text { moderate anxiety } 1 \\
\text { levels. }\end{array}$ \\
\hline 8 & P. Sindu & $\begin{array}{l}\text { Management of depression with } \\
\text { behavior therapy }\end{array}$ & $\begin{array}{l}\text { Bharathiar } \\
\text { University, } \\
\text { Coimbatore, India }\end{array}$ & $\begin{array}{l}\text { Quasi experimental } \\
\text { design }\end{array}$ & $\begin{array}{l}\text { Depression } \\
\text { Anxiety and Stress } \\
\text { Scale- } 21 \\
\text { (DASS21) }\end{array}$ & $\begin{array}{l}\text { One hundred studes } \\
\text { to participate in th } \\
\text { three-month psych } \\
70 \% \text { to } 90 \% \text { of col } \\
\text { stress after undergc }\end{array}$ \\
\hline
\end{tabular}

Table 1 : Synthesis Grid 


\section{Discussion}

Based on the search results, 8 articles have been found that match the inclusion criteria. The studies that have been selected relate to the level of anxiety of midwifery students in facing the Labskills exam (Laboratory Skills). Based on the results of a review of the 8 articles, they are discussed in the discussion below.

\subsection{Characteristics of students}

The prevalence of anxiety can be associated with a very limited time change when facing a skill laboratory exam. This is exacerbated by changes in student lifestyles, thoughts of succeeding or failing in exams, and other factors such as demographics and socio-economics of students' personalities. Students in this case need coping strategies, one of which can be done together with parents and college friends (Shamsuddin, 2013).

Medical faculties around the world show that the number of male students is less than the number of female students. The group of male students is a minority which makes the level of anxiety higher than female students (Roh, 2010).

Students as individuals who are less sociable or introverted have the potential to experience anxiety at a severe stage because each individual must at least express their emotions. Support from the closest people such as parents and friends is needed to minimize students' anxiety levels, especially when facing exams (Cohen, 1985).

In line with the opinion of Sarafino (2010), social support is a feeling of pleasure, attention, appreciation, or assistance given by other people or groups given to oneself who are in of need social support. Someone who has received social support will develop a sense of confidence in them that they are loved, cared for, and feel worthy. In the end they will be more enthusiastic in living their lives (Sarafino, 2010).

\subsection{Anxiety about exams}

In principle, anxiety refers to restlessness caused by fear of misfortune or danger. In a study conducted by Barry et al (2011), anxiety within the permissible limits is normal and understandable but, when the anxiety level increases, then help is needed to calm the people down (Barry et al, 2011)

Anxiety during laboratory skills examinations is an important problem amongst students as it often relatable with decrease in performance and severe psychological problems. Mosaviy et al (2018) reported poor academic performance in students who had high test anxiety scores. Increasing anxiety will result in reduce in academic performance. Furthermore, it is still unclear if academic performance itself will cause anxiety

\subsection{Strategies for dealing with anxiety}

According to WHO (2013), students are encouraged to spend sufficient time in their social and personal lives and emphasize the importance of coping strategies in overcoming the anxiety they face. In terms of academic management, student

Counseling Centers with adequate facilities and qualified staff should be established on campus as a medium for students to seek appropriate help for mental health problems. In addition, anxiety prevention efforts are introduced early starting in early education (Dordinejad, 2011)

Signs and symptoms of anxiety should be addressed as soon as possible. Anxiety causes high losses for midwifery students such as dropping out of college, suicidal tendencies, problems with parents and peers, disruption of the learning process, and also health problems (Radeef, 2014).

\subsection{Interventions to reduce anxiety levels}

Depression is considered the most common disease in the world, but in its treatment, it is still considered very little attention. The prevalence of depression and anxiety kept on increasing and WHO estimated that the world will reach the higheset level of disability and mental disorder globally by 2030 (WHO, 2004). Students experience 
stress when they are unable to handle longing for someone, fear of failure, emotional problems, low self-esteem, family problems, and social difficulties in dealing with other students. College life brings its own set of stresses and anxieties (Wang, 1997).

Interventions to deal with depression, anxiety, and stress are very important considering the high annual suicide rate (Roy, 2015)

Around 49,250 students have attempted suicide between 2011 and 2016 in India. Experimental interventions have been shown to be effective to treat depression, anxiety, and stress. In addition, psychoeducation which includes time management, anger management, anxiety management, problem solving and decision making, goal setting, self-management skills, assertive communication, challenging negative thoughts, and stress management has been shown to reduce levels of depression, anxiety, and stress drastically (Sindu, 2020).

\section{Conclusion}

Students are expected to make the best possible adaptations to avoid the occurrence of anxiety which will result in such as decreased concentration in learning, disturbed attention, decreased achievement index, restlessness or loss of control of a problem solving. Anxiety that is increasingly becoming a problem can be overcome by managing and controlling oneself and a psychological education can be carried out that will ease the burden on students' minds and reduce student anxiety and it is hoped that students will be of higher quality so that they can be pawns of the success of the SDGs program in improving maternal and child health.

\section{Acknowledgements}

We would like to extend our gratitude first to God for providing life. Next would be for the midwifery study program of the airlangga medical faculty who has agreed to become a respondent in this research. We would also like to acknowledge Ivon Diah Wittiarika, S.Keb.Bd.,M.Kes and Samriyaningsih Handayani, dr., M.Kes., M.Ed., $\mathrm{Ph} . \mathrm{D}$, for constantly reviewing, giving comments on this paper and most especially in encouraging me to finish this paper. We are also deeply thankful to our family and loved ones for the love, tenderness, and concern throughout the time and when we forgot to take a break for ourselves in making this work.

\section{References}

Barry, M., Noonan, M., Bradshaw, C. and Murphy, S.T. (2011) An exploration of student midwives' experiences of the objective structured clinical examination assessment process. Nurse Education Today, 32, 690-694 www.elsevier.com/nedt,2011,YNEDT02095:5

Bergmann, C., Muth, T. and Loerbroks, A. (2019) "Medical studentse perceptions of stress due to academic studies and its interrelationships with other domains of life: a qualitative studyee, Medical education online. Taylor \& Francis, 24(1), p. 1603526. doi: 10.1080/10872981.2019.1603526.

Bruhl, A., Rufer, M. and Herwig, U., 2012. S.14.02 Update of neuroimaging in social anxiety disorder. European Neuropsycho pharmacology, 22, $\quad$ pp.S131-S132

Cohen, S. and Wills, T.A. (1985) Stress, Social Support, and the Buffering Hypothesis. Psychological Bulletin, 98, $310-357$.

http://psycnet.apa.org/journals/bul/98/2/31

Dordinejad, F.G., Hakimi, H., Ashouri, M., Dehghani, M., Zeinali, Z., Sadegh Daghighi, M. and Bahrami, N. (2011) On the relationship between test anxiety and academic performance. Procedia Social and Behavioral Sciences, 15, 3774-3778.

Duffy ME, Twenge JM, Joiner TE. Trends in mood and anxiety symptoms and suiciderelated outcomes among undergraduates U.S. 20072018: Evidence from two national surveys. Journal of Adolescent Health. 2019;65(5):590- 598.

Faramarzi, M., Pasha, H., Bakhtiari, A., Salmalian, H., Delavar, M., Amiri, F. and Nikpour, M., 2013. Test anxiety in objective structured clinical examinations (OSCEs) compared with traditional assessment methods in undergraduate midwifery students. Health, [online] 05(12), pp.2204-2209. Available at: https://www.scirp.org/journal/paperinformatio n.aspx?paperid=41474 [Accessed 1 November 2021].

Kaplan., Sadock. 2005. Gangguan ansietas, Tangerang : Binarupa Aksara.

Martua, E., Wendra, S. and Simon, E., 2019. Comparison of Anxiety Level on Medical Skill Examination Between Students of Medical Faculty of Hang Tuah University Surabaya in 1st Semester Who Have Received Mental Health Tests During The Entrance Test with 3rd Semester Who Have Not. Oceana Biomedicina Journal, [online] 2(1), p.20.

Available at: https://media.neliti.com/media/publications/290282-comparison-of-anxiety-level-on-medical-s-f6204fb6.pdf [Accessed 1 November 2021].

Mousavi, M., Haghshenas, H., Alishahi, M. and Najmi, B. (2008) Anxiety test and some correlated socio-demographic factors in high school students. Shiraz Journal of Research in Behavioural Sciences, 6, 17-25.

Neuderth, S., Jabs, B. and Schmidtke, A. (2009) Strategies for reducing test anxiety and optimizing exam preparation in German uni versity students: A preventionoriented pilot project of the University of Würzburg. Journal of Neural Transmission, 116, 785-790. http://dx.doi.org/10.1007/s00702-008-0123-7

PP IBI.2016.Buku Acuhan Midwifery Update.Cetakan 1. Jakarta: Pengurus Pusat Ikatan Bidan Indonesia.

Radeef, A.S., Faisal, G.G., Ali, S.M. and Ismail, M.K.H.M. (2014) Source of Stressors and Emotional Disturbances among Undergraduate Science Students in Malaysia. International Journal of Medical Research \& Health Sciences, 3, 401-410. http://ijmrrhs.com/source- 
of-stressors-andemotional-disturbances-amongundergraduate-science-studentsinmalaysia/http://dx.doi.org/10.5958/j.23195886.3.2.08

Rasmun. (2009). Stress Koping dan Adaptasi. CV. Sagung Seto. Jakarta

Ravichandran, K., Dewi, D., Aryabiantara, I. (2020). The characteristic of anxiety disorder among medical students of Universitas Udayana, Bali, Indonesia in the 2019 period. Intisari Sains Medis 11(3): 1264-1270. DOI:10.15562/ism.v11i3.692

Roh MS, Jeon HJ, Kim H, Han SK, Hahm BJ. The prevalence and impact of depression among medical students: a nationwide crosssectional study in South Korea. Acad Med 2010; 85(8): 1384-1390.

Roy, P.P, Kumar, S.S., Doshi, M.A., 2015. Depression, anxiety and stress among first year undergraduate medical students. Asian J.

Biomed. Pharm. Sci. 37-38.

Sansone, R. A. and Sansone, L. A. (2007) „Physician and medical student stress ${ }^{\text {ee }}$ Psychiatry (Edgmont (Pa. : Township)). Matrix Medical Communications, 4(3), pp. 28-29. Available at: https://pubmed.ncbi.nlm.nih.gov/20805907.

Sarafino, E.P. (2010). Health Psychology : Biopsychosocial Interactions. Fifth Edition.USA : John Wiley \& Sons.

Shamsuddin, K., Fadzil, F., Wan Ismail, W.S., Azhar Shah, S., Omar, K., Muhammad, N.A., et al. (2013) Correlates of Depression, Anxiety and Stress among Malaysian University Students. Asian ournal Psychiatry,6,318323.http://www.researchgate.net/publication/243966318_Correlates_of_depression_anxiety_and_stress_among_Mal aysian_university_students. http://dx.doi.org/10.1016/j.ajp.2013.01.014

Sindu, P., 2020. Management of depression with behavior therapy. Current Research in Behavioral Sciences, [online] 1, p.100001. Available at: https://www.sciencedirect.com/science/article/ pii/S2666518220300012 [Accessed 1 November 2021]

Wang, Q., 1997. The effect of psychological education on mental health status of middle school students. Chin. Ment. Health J. 284-285

Werner-Seidler, A., Perry, Y., Calear, A., Newby, J. and Christensen, H., 2017. Schoolbased depression and anxiety prevention programs for young people: A systematic review and meta-analysis. Clinical Psychology Review, 51, pp.30-47.

World Health Organisation, The Global Burden of Disease. https://www.who.int/healthinfo/global_burden _disease/2004_report_update/en/,2004.

World Health Organization (2013) WHO Definition of Health. WHO, Geneva. http://www.who.int/about/definition/en/print.h tml

Yang, R., Lu, Y., Chung, M. \& Chang, S. (2014). Developing a short version of the test anxiety scale for baccalaureate nursing skills test - A preliminary study. Nurse Education in Practice, vol. 14, no. 6, pp. 586-590.

Yusoff, M., Mat Pa, M., Esa, A. and Abdul Rahim, A., 2013. Mental health of medical students before and during medical education: A prospective study. Journal of Taibah University Medical Sciences, [online] 8(2), pp.86-92. Available at:https://www.sciencedirect.com/science/article/pii/S1658361213000346 [Accessed 1 November 2021]. 